\title{
Evaluation of French bean (Phaseolus vulgaris L.) genotypes for seed production
}

\author{
R. Das*, U. Thapa, S. Debnath, Y. A. Lyngdoh and D. Mallick \\ Nadia - 741252 (West Bengal), INDIA \\ *Corresponding author. E-mail: rajib_bckv@yahoo.co.in \\ Received: August 21, 2014; Revised received: September 15, 2014; Accepted: November 03, 2014
}

Department of Vegetable Crops, Faculty of Horticulture, Bidhan Chandra Krishi Viswavidyalaya, Mohanpur,

\begin{abstract}
An experimental study was conducted during 2011/2012 and 2012/2013 at Horticulture Research Station, Mondouri, Bidhan Chandra Krishi Viswavidyalaya, Monhanpur, Nadia, West Bengal, India, to evaluate the performance of fourteen different bush type French bean genotypes for seed yield and to study varietal characterization based on plant morphology. The genotypes, studied under this experiment were namely, Abhay, Shillong Local-3, Arjun, Selection-9, Arka Anoop, Arka Komal, Badshah, Anupam, Arka Suvidha, Falguni, Sonali, Local, Victoria and Vaishnavi-264. From overall point of view of the outcome of the experiment, it has been revealed that genotype with relatively bolder seeds with more number of seeds per pod, and higher bearing capacity per plant generally gives higher seed yield. Among the genotypes under study, Arka Suvidha was the best one as it produced the highest seed yield (2180.92 kg/ha) and relatively good plant vigour and fairly high seed vigour index (2944.38). Falguni and Mohanpur Local also can be considered promising once for seed production point of view.
\end{abstract}

Keywords: French bean, Genotypes, Seed production, Seed quality, Yield

\section{INTRODUCTION}

Seed is considered as the basic critical and vital input for enhancing and stabilizing productivity of different vegetable crops, harnessing higher net monitory returns per unit area, input and time of different vegetable crops. Good seed therefore, is the basis or critical input upon which all other inputs will depend for their full effectiveness. According to Food and Agricultural Organization (FAO) of United Nations, India is the world leader in production of dry seed of french bean followed by Brazil and Myanmar. On the other hand China is world leader in production of green beans followed by Indonesia and then Turkey (FAOSTAT, 2010). Scarcity of quality seed is one of the major hinders faced by the French bean growers of the plains of West Bengal for producing quality French bean pod. Although there is greater scope for seed production of French bean during winter season in the plains of West Bengal. Genotype is the most important factor in any crop production programme and is the basic material to which all other technologies are applied (Goutam et al., 2001). Therefore, unless a good genotype of high potential is used; other technologies will also not work. These genotypes are also greatly varied in their performance under different agro-climatic conditions of the country which often creates confusions among the farmers about their choice of variety. So, selection of particular variety for seed production is also prime important for higher seed yield. Hence, it is essential to look forward for the production of quality seed in the state itself to uplift quality production of French bean. In this back drop, the present experiment was undertaken with the objectives to study the performance of French bean genotypes for seed yield and its varietal characterization based on plant morphology.

\section{MATERIALS AND METHODS}

This present experiment was conducted at Horticulture Research Station, Mondouri, Bidhan Chandra Krishi Viswavidyalaya, Mohanpur, Nadia, West Bengal for two winter seasons during 2011/2012 and 2012/2013. The soil of experiment site is sandy loam in nature with around $0.57 \%$ organic carbon, $0.06 \%$ total nitrogen, available Phosphorous $30.10 \mathrm{~kg} / \mathrm{ha}$, available Potassium $115.7 \mathrm{~kg} / \mathrm{ha}$ and $\mathrm{pH}$ 6.5. The experimental site is under subtropical humid region with range of average temperature of $25^{\circ} \mathrm{C}$ and $12^{\circ} \mathrm{C}$ during the experimental period (November to March) of both the years. Fourteen genotypes of French bean under bush type were evaluated to assess growth, flowering and yield attributing characters of plants and seed and quality parameters of seed to screen out for best performing genotype for seed production purposes. Preliminary information on fourteen genotypes are given in Table 1.

The experiment was laid out in Randomized Block Desing with 3 replications of each treatment. French bean seeds were sown in the field at a spacing of 60 $\mathrm{cm} \times 30 \mathrm{~cm}$ in plots of $2.4 \mathrm{~m} \times 2.1 \mathrm{~m}$ size. Number of 
Table 1. Preliminary information on fourteen genotypes.

\begin{tabular}{ll}
\hline Genotypes & \multicolumn{1}{c}{ Source } \\
\hline Abhay & Bharat Nursery Pvt. Ltd. \\
Shillong local-3 & Shillong \\
Arjun & Debgiri Agro Products Pvt. Ltd. \\
Selection-9 & Chakra Seeds \\
Arka Anoop & IIHR \\
Arka Komal & IIHR \\
Badsah & Debgiri Agro Products Pvt. Ltd. \\
Anupam & Debgiri Agro Products Pvt. Ltd. \\
Arka Suvidha & IIHR \\
Falguni & Seminis Monsanto Holding Pvt. \\
Sonali & Ltd. \\
Local & Bharat Nursery Pvt. Ltd. \\
Victoria & Mohanpur \\
Vaishnavi-264 & Chrystal Crop Sciences Ltd. \\
\hline
\end{tabular}

plants per plot was 28. Normal cultural practices were followed and plant protection measures, particularly against white fly, were taken by spraying Hamla 550 [Chloropyriphos + Cypermethrin $(50 \%+50 \%)$ E.C.]. The mentioned chemical was spread in two times at 10 days interval during the cultivation process. Pooled mean values of the parameters in each replication were statistically analyzed following Randomized Block Design. The 'Table' formulated by Fisher and Yates (1963) were consulted for the purpose of comparison of ' $F$ ' values and for determination of critical differences (C.D. values) at the probability of 0.05 .

\section{RESULTS AND DISCUSSION}

Growth and flowering characters: The representation of mean data of various growth and flowering characters of all the French bean varieties in Table 2 are showing significant variations.

With respect to plant height the highest value was obtained in case of the genotype Badsah $(47.53 \mathrm{~cm})$ and lowest for the genotype Abhay $(25.67 \mathrm{~cm})$. Considering the number of branches per plant was recorded as the highest for the variety Anupam (3.73) and lowest in case of Selection-9 (2.03). Leaf number per plant counted as maximum for the variety Arjun (20.93) and minimum for the variety Falguni (12.13). From the results and discussion of these plant growth parameters it can be concluded that under the agro-climatic condition of the experimental site in general, a good plant vigour has been shown by Arjun, Badsah, Sonali, Vaishnavi- 264, Arka Suvidha, Falguni, Mohanpur Local where as comparatively poor plant vigour given by genotype like Abhay, Victoria, Arka Komal etc. The differences in the plant growth characters may be due to the genetic variability within the genotype itself or may be due to the environmental effects.
Amongst the genotypes in case of duration taken from sowing to first flowering Mohanpur Local took 41 days followed by Selection-9 and Arka Anoop (41.36 days and 42 days respectively). They differed statistically significantly from other genotype and can be considered as early flowering once. Whereas, the longest duration for first flowering has been recorded for Falguni and Abhay (49 days) followed by Victoria (48.33 days). These can be considered as late flowering genotype. With respect to duration taken for $50 \%$ of the plant population of each genotype to come into flowering showed almost similar result comparing to duration taken for first flowering from sowing. Keeping in view the days taken to pod set or fruit set from $50 \%$ flowering longest duration has been observed for Shillong Local-3 (5.66 days). Whereas, the least time was taken by Anupam (3.33 days), Arka Suvidha, Falguni and Mohanpur Local (4, 30, 4.66, 4.66 days respectively). Similar findings with respect to days taken to pod set from $50 \%$ flowering in common bean has been reported by Kamaluddin and Shahid-Ahmed (2011).

Yield attributing characters: The data pertaining to yield attributing characters are presented in Table 3. Yield attributing characters were affected significantly within genotypes.

Pod length differed in a considerable manner among genotypes which was highest for Shillong Local-3 $(19.37 \mathrm{~cm})$ and lowest for Falguni $(12.96 \mathrm{~cm})$. In general consideration, it can be concluded from the result that varieties like Shillong Local-3, Selection-9, Arka Komal, Mohanpur Local, Arka suvidha produced relatively longer pods whereas the varieties like Falguni, Arka, Anoop and Sonali having relatively smaller pod size. Highest pod girth was measured as $12.23 \mathrm{~mm}$ from the variety Shillong Local-3 and lowest from Falguni (7.06 mm). Varieties like Arka Suvidha, Mohanpur Local, Arka Komal, Arka Anoop, Selection-9 having intermediate pod girth ranging from 10 to $11 \mathrm{~mm}$. The genotype included in the study produced an average variation of number of pods per plant was 7.45 to 20.19. Among the genotypes, Arjun produced maximum number of pods per plant (20.19) followed by Arka Suvida (19.52) and Sonali (19.18). Mature pod yield obtained the highest for the variety Arka Suvidha (43.83 g/plant) followed by Falguni (42.57 g/plant). The lowest mature pod yield obtained from Shillong Local-3 (11.49g/plant). The highest number of seed per pod was observed on Vaishnavi - 264 (6.83) followed by Arjun (6.33), Abhay (6.20). Arjun and Abhay are statistically at par but both of them differed significantly from Vaishnavi- 264 (6.83). The results are corroborated with the findings of Shukla et al. (2006). Their finding revealed that number of pods per plant had a positive contribution to seed yield. The genotype produced longest seed length and widest seed girth was Arka Suvidha $(1.56 \mathrm{~cm}$ and $7.56 \mathrm{~mm})$ followed by Mohanpur Local $(1.55 \mathrm{~cm}$ and $7.33 \mathrm{~mm})$. 
Table 2. Performance of different French bean genotypes for growth and flowering characters.

\begin{tabular}{lcccccc}
\hline Genotypes & $\begin{array}{c}\text { Plant } \\
\text { height }(\mathbf{c m})\end{array}$ & $\begin{array}{c}\text { Number of } \\
\text { branches/ } \\
\text { plant }\end{array}$ & $\begin{array}{c}\text { Number of } \\
\text { leaves/plant }\end{array}$ & $\begin{array}{c}\text { Days to 1 } \\
\text { Flowering }\end{array}$ & $\begin{array}{c}\text { Days to 50\% } \\
\text { flowering }\end{array}$ & $\begin{array}{c}\text { Days to pod set } \\
\text { from 50\% } \\
\text { flowering }\end{array}$ \\
\hline Abhay & 25.67 & 3.00 & 13.80 & 49.00 & 52.33 & 4.00 \\
Shilollong & 34.20 & 2.87 & 15.47 & 41.67 & 46.67 & 5.66 \\
Local-3 & 44.46 & 3.20 & 20.93 & 43.00 & 47.00 & 4.33 \\
Arjun & 42.67 & 2.53 & 13.73 & 42.00 & 47.00 & 4.33 \\
Selection-9 & 31.40 & 2.80 & 15.27 & 43.67 & 48.67 & 4.66 \\
Arka Anoop & 35.20 & 3.47 & 10.73 & 43.33 & 49.67 & 5.00 \\
Arka Komal & 47.53 & 2.87 & 15.07 & 44.00 & 47.67 & 4.00 \\
Badsah & 43.00 & 3.73 & 15.93 & 44.00 & 48.33 & 3.33 \\
Anupam & 34.07 & 3.27 & 20.93 & 43.33 & 47.33 & 4.00 \\
Arka Suvidha & 30.40 & 2.60 & 12.13 & 49.00 & 51.67 & 3.66 \\
Falguni & 44.00 & 2.87 & 13.73 & 43.67 & 49.33 & 4.33 \\
Sonali & 41.53 & 2.53 & 19.27 & 41.00 & 46.00 & 4.66 \\
Local & 32.13 & 2.93 & 14.13 & 48.33 & 50.67 & 5.00 \\
Victoria & 45.27 & 3.20 & 19.27 & 44.33 & 50.33 & 3.66 \\
Vaishnavi-264 & 1.72 & 0.19 & 1.02 & 0.51 & 0.41 & 0.45 \\
S.Em. ( \pm ) & 4.15 & 0.45 & 2.46 & 1.23 & 0.99 & 1.08 \\
CD (5\%) & & & & & & \\
\hline
\end{tabular}

So, they can be considered as bolder seeded genotype. Genotype with lowest seed length \& seed girth was Falguni, Sonali, Victoria, Arjun etc. So, they can be considered as lighter seeded genotype. The genotypic differences on seed length in pole type French bean have also been reported by Pandey et al. (2011). 100 seed weight showed direct positive correlation with the seed size. These results are in consensus with the findings of Coimbra et al. (1998) in French bean.

As per as seed yield is concerned the highest seed yield/plant, per plot and per hectare was obtained from Arka Suvidha (39.56 g, $1099.19 \mathrm{~g}$ and $2180.92 \mathrm{~kg}$ respectively) followed by Falguni (36.86g, $1032.25 \mathrm{~g}$ and $2047.97 \mathrm{~kg}$ respectively) and lowest result in this respect was shown by Shillong Local-3 $(5.56 \mathrm{~g}$, $155.81 \mathrm{~g}$ and $312.84 \mathrm{~kg}$ respectively). Relatively good seed yield has been produced by Arjun, Vaishnavi-264, and Anupam etc whereas, Badsah, Abhay, Victoria, Arka Anoop gave relatively lesser seed yield.

Seed quality parameters: Seed quality parameters amongst the genotypes (Table 3) clearly indicated that there were significant differences present among the genotypes under study.

Germination percentage of the harvested seed was measured highest for the variety Mohanpur Local $(99 \%)$ and lowest for the variety Victoria $(38.50 \%)$.
The varieties which showed relatively higher germination percentage were Mohanpur Local (95.5) Badsah (92.45\%), Arka Suvidha (86.53\%), Shillong Local-3 $(84.22 \%)$. Seedling root length measured at $9^{\text {th }}$ day of germination was highest for Shillong Local-3 $(14.83 \mathrm{~cm})$ whereas it was obtained as lowest for Falguni $(8.90 \mathrm{~cm})$. With respect to seedling shoot length the maximum was observed of $26.43 \mathrm{~cm}$ with Vaishnavi- 264 and the minimum of $11.57 \mathrm{~cm}$ was obtained from Abhay. Keeping in view towards the seed vigour index Badsah can be considered as the best variety having a seed vigour index of 3473.50 followed by Mohanpur Local (3439.10). The lowest seed vigour index was obtained from the variety Abhay (1201.33). Relatively higher seed vigour in some genotype may be due to cumulative effect of higher shoot length, root length and germination percentage which were greatly influenced by genotype with bold seed character. Similar findings have been revealed by Chaudhury et al. (2004) in the experiment with different French bean genotypes. Seed protein percentage varied from 16.50 to $17.19 \%$. The character seed protein content showed a narrow range of variation among the genotype where highest seed protein content has been recorded with Arjun (17.19\%) but it was statistically at par with Arka Komal 


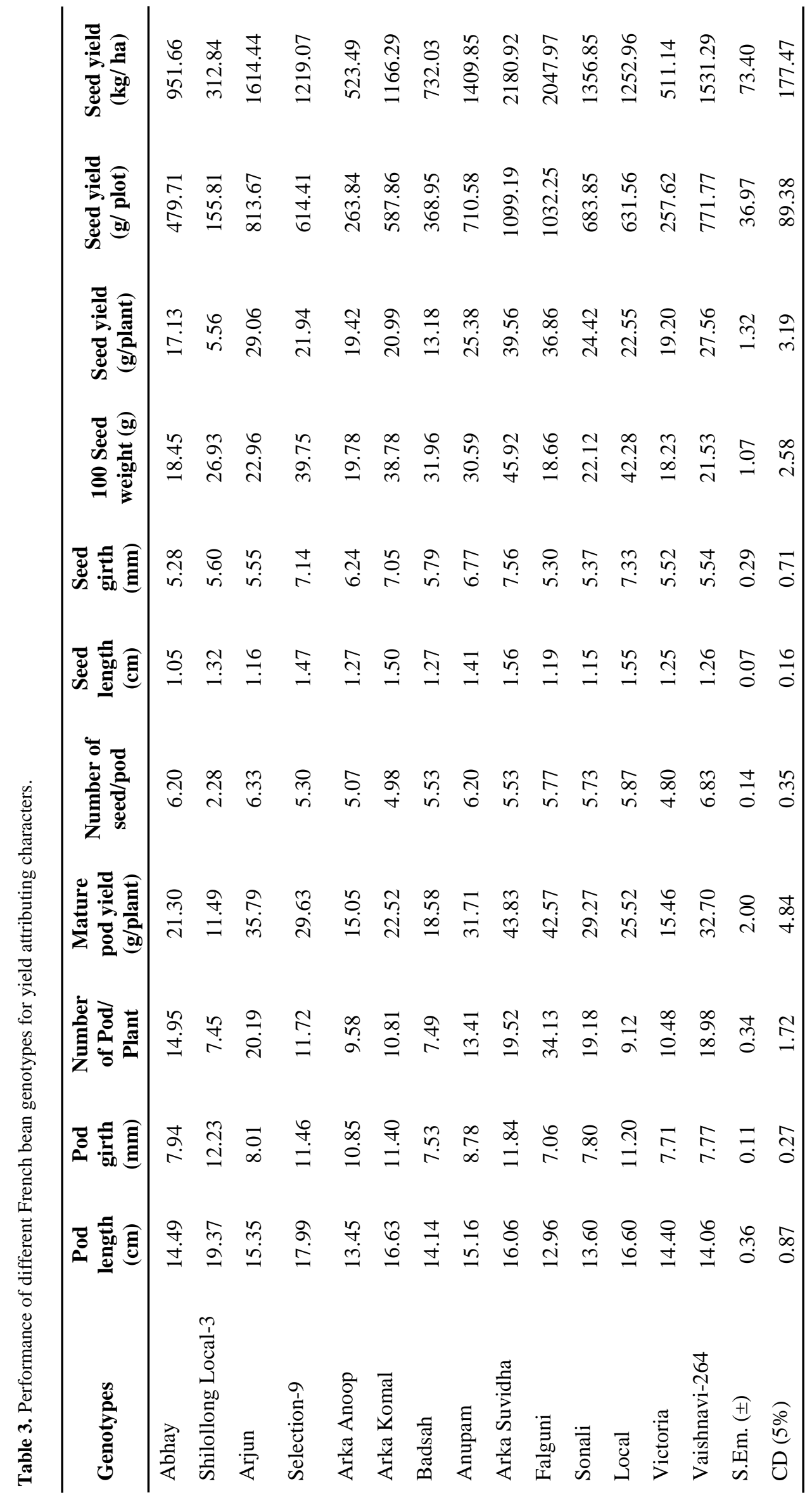


Table 4. Performance of different French bean genotypes for seed quality characters.

\begin{tabular}{lccccc}
\hline Genotypes & Germination $\%$ & $\begin{array}{c}\text { Root length } \\
(\mathbf{c m})\end{array}$ & $\begin{array}{c}\text { Shoot length } \\
(\mathbf{c m})\end{array}$ & $\begin{array}{c}\text { Seed vigour } \\
\text { index }\end{array}$ & $\begin{array}{c}\text { Seed protein } \\
(\boldsymbol{\%})\end{array}$ \\
\hline Abhay & 69.50 & 5.73 & 11.57 & 1201.33 & 16.55 \\
Shilollong Local-3 & 84.22 & 14.83 & 20.70 & 2993.96 & 16.79 \\
Arjun & 68.05 & 14.40 & 19.73 & 2326.61 & 17.19 \\
Selection-9 & 80.36 & 11.23 & 21.00 & 2589.36 & 16.55 \\
Arka Anoop & 43.28 & 10.57 & 21.88 & 1403.45 & 16.55 \\
Arka Komal & 55.93 & 11.76 & 21.03 & 1832.74 & 17.15 \\
Badsah & 92.45 & 12.63 & 25.10 & 3473.50 & 16.72 \\
Anupam & 78.05 & 12.87 & 25.93 & 3026.89 & 16.69 \\
Arka Suvidha & 86.53 & 12.20 & 21.83 & 2944.38 & 16.50 \\
Falguni & 51.62 & 8.90 & 18.20 & 1445.91 & 16.81 \\
Sonali & 77.89 & 12.70 & 25.36 & 2963.76 & 16.91 \\
Local & 95.55 & 13.40 & 22.63 & 3439.10 & 16.73 \\
Victoria & 38.50 & 11.60 & 21.60 & 1277.08 & 16.42 \\
Vaishnavi-264 & 38.66 & 13.03 & 26.43 & 1523.87 & 16.71 \\
S.Em. $( \pm)$ & 1.85 & 0.27 & 0.38 & 32.41 & 0.22 \\
CD (5\%) & 4.46 & 0.65 & 0.92 & 196.77 & 0.54 \\
\hline
\end{tabular}

(17.15\%), Sonali (16.91\%), Falguni (16.81\%), Shillong Local-3 (16.79\%), Mohanpur Local (16.73\%), Badsah (16.72\%), and Vaishnavi- 264 (16.71\%).

\section{Conclusion}

From overall point of view of the results and discussion it can be concluded that genotype with relatively bolder seeds with more number of seeds per pod, and higher bearing capacity per plant generally gives higher seed yield. Among them, Arka Suvidha was the best one as it produced highest seed yield and relatively good plant vigour and fairly high seed vigour index. This may be due to the fact that the agro-climatic condition of the experimental side during the cropping season best suited for this genotype. Among the other genotypes Falguni and Mohanpur Local also can be considered promising once for seed production point of view. Here from, it may be pointed out that while initiating the seed production programme as a commercially lucrative venture for French bean mostly in the New Alluvial plains of West Bengal, one may consider varieties like Arka Subidha, Falguni and Mohanpur Local as the most promising once due their relatively good plant vigour and high seed yield potentiality.

\section{REFERENCES}

Chaudhury, K., Sannigrahi, A.K. and Singh, B. (2004).
Varietal evaluation of French bean for Assam plains, Environment and Ecology. 17(1): 236-237.

Coimbra, J.L.M., Guidolin, A.F., Carvalho, F.I.F. De. and Duarte, I.A. (1998). Quantitative analysis of genetic and phenotypic parameters in bean (Phaseolus vulgaris L.). Pesquisa Agropecuaria Gaucha, 4(2): 157-165.

FAOSTAT. (2010). Data Food and Agricultural Organization (FAO) of United Nations. htm.

Fisher, R. and Yates, F. (1963). Statistical table for biological, agricultural and medical researchers, $6^{\text {th }}$ ed. Oliver and Boyd Ltd., London. 146 p.

Goutam, P., Mulani, S. and Arvind, G. (2001). Evaluation of Genetic Diversity in Some pea varieties Grown in North-Eastern hills. Indian Journal of Hill Farming, 6 (2): $27-28$.

Kamaluddin, S. and Shahid, A. (2011). Variability, Correlation and path analysis for seed yield and yield related traits in common beans. Indian Journal of Horticulture, 68 (1): $56-60$.

Pandey, Y.R., Gautam, D.M., Thapa, R.B., Sharma, M.D. and Paudyal, K.P. (2011). Evaluation of pole-type French bean genotypes in the mid hills of western Nepal. Journal of Nepal Agriculture Research, pp. 80-86.

Shukla, S.K., Mahajan, V., Majumdar, N.D., Tiwari, V., Prasad, S.V.S. and Gupta, H.S. (2006). Evaluation of rajmah (Phaseolus vulgaris L.) genotypes in mid-altitudes North-West Himalayas. Indian Journal of Genetics and Plant Breeding, 66(4): 345-346. 